\title{
半導体集積回路の配線に用いる銅めっき膜の不純物
}

\author{
上 野 和 良 ${ }^{\mathrm{a}}$ \\ a 芝浦工業大学工学部 ( ₹ 135-8548 東京都江東区豊洲 3-7-5)
}

\section{Impurities in Electroplated Copper Films for LSI Interconnection}

Kazuyoshi UENO a

${ }^{a}$ College of Engineering, Shibaura Institute of Technology(3-7-5, Toyosu, Koto-ku, Tokyo 135-8548)

Keywords : Copper, Electroplating, Impurity

\section{1.はじめに}

半導体集積回路においては, 1997 年頃以降, 微細配線に 電気めっきによる銅 $(\mathrm{Cu})$ が用いられるようになった ${ }^{1)}$ 。その 理由は, $\mathrm{Cu}$ 配線がそれ以前に用いられてきたアルミニウム 合金の配線に比較して, 低抵抗で電流密度耐性が高いため, 微細化に伴う配線遅延の増加や信頼性劣化の対策として必要 になったからである。微細 $\mathrm{Cu}$ 配線は図 1 に示すように, 絶 縁膜の溝 (トレンチ)や孔 (ビア)に金属を埋め込んだ後, 化学 的機械研磨 (CMP : Chemical Mechanical Polishing)で不要な金属 を除去・平坦化するダマシン (Damascene) 法で形成される ${ }^{2,3)}$ 。 金属の埋め込みには, トレンチやビアの表面にスパッ夕法に よって堆積したバリア膜やシード膜 $(\mathrm{Cu})$ 上に, 電気めっき によって銅を埋め込む方法が用いられる。バリア膜は $\mathrm{Cu}$ の 拡散を防止する膜でタンタル $(\mathrm{Ta})$ や窒化タンタル $(\mathrm{TaN})$ が主 に用いられる。

半導体集積回路では, Moore の法則に従って 2 年から 3 年 ごとの周期で集積度を 2 倍に増加させるため, 素子寸法を約 0.7 倍に比例縮小してきた。その結果, 現在では微細配線の 幅は $50 \mathrm{~nm}$ 程度の寸法になっている。また, トレンチやビア の縦と横の寸法比(アスペクト比) は, 微細化に伴い増加する 傾向にあるが, それぞれ 2 程度で合わせて 4 程度である ${ }^{4), 5)}$ 。

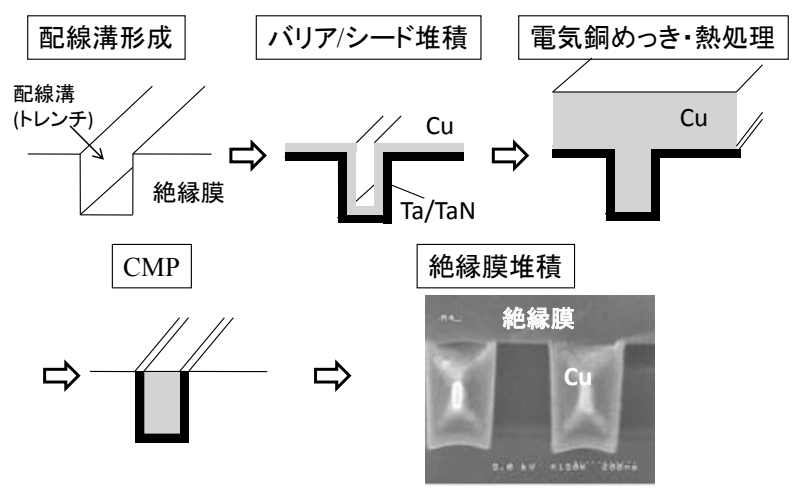

図 1 ダマシン法による $\mathrm{Cu}$ 配線の形成プロセスと断面 SEM 写真
このような微細・高アスペクト比のパターンへの銅の埋め込 みを実現するため, めっきプロセスにはボトムアップフィリ ングあるいはスーパーフィリングと呼ばれる方法が用いられ る ${ }^{6) \sim 11)}$ 。ボトムアップフィリングは, めっき液に添加する添 加剂の作用で実現されるが, 微細になるほど埋め込みが困難 になるとともに, 添加剤による不純物の影響が懸念されている。 本稿では, 微細配線に用いる銅めっき膜に関して, 膜中の 不純物とそれらの影響について解説する。

\section{2. 半導体集積回路の配線に用いる $\mathrm{Cu}$ めっき}

微細配線の形成にはボトムアップめっきが用いられる。ボ トムアップめっき浴では, 硫酸銅と硫酸からなる基本浴に, 塩素, 抑制剂(サプレッサ), 促進剂(アクセラレータ), レベ ラーなどと呼ばれる添加剤が添加される。サプレッサはポリ マーとも呼ばれ，分子量の大きい Polyethylene glycol (PEG) が主として用いられる。図 2 は, ボトムアップめっきの様子 と各添加剂の作用を模式的に示している。分子量の大きなサ プレッサは，塩素と複合体を形成してめっき液からの $\mathrm{Cu}$ の 析出を抑制する作用を持ち，微細パターン内には侵入しにく いため, 主にトレンチやビアの側面や外の平坦部での $\mathrm{Cu}$ 析 出を抑制する。サプレッサ単独でもトレンチやビア内の析出

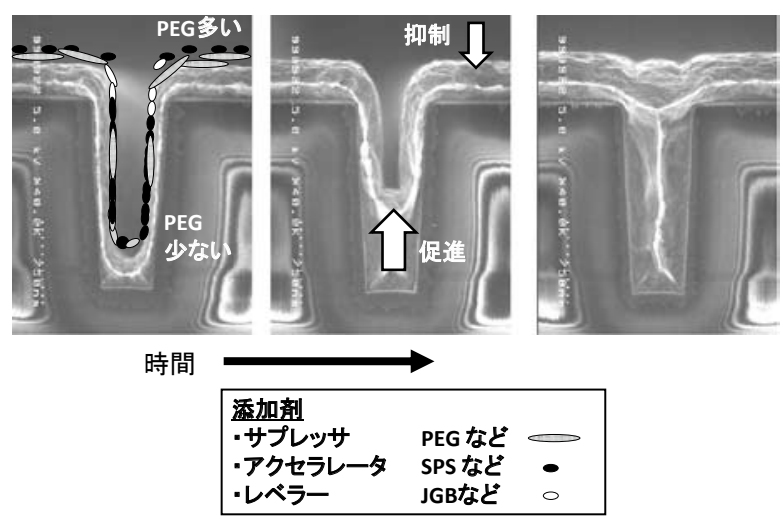

図 2 ボトムアップめっきの様子と添加剤の作用の模式図 
速度が相対的に速くなるので，ボトムアップ堆積ができる。 アクセラレータは, $\mathrm{Cu}$ の析出を助ける作用のある分子で, Bis- (sodium sulfopropyl) -disulfide (SPS)などが用いられる。 SPS は分子量が小さいため物理的形状も小さく, トレンチや ビアの中にも侵入しやすい。その結果, パターン内部では, アクセラレータのサプレッサに対する相対的な濃度が増加し, 抑制作用が弱くなり, パターン外部より $\mathrm{Cu}$ 析出速度が相対 的に速くなり, ボトムアップ堆積の特性が助長される。また ビアの底から $\mathrm{Cu}$ が堆積するにつれて, 堆積表面にアクセラ レータが集まり, 堆積がさらに促進されるモデルも考えられ ている ${ }^{12), 13)}$ 。レベラーは, パターンの角部に吸着しやすく, その部分での析出を抑制するとされており, Janus Green B (JGB)などが用いられ, 添加されない場合もある。市販のめっ き液では，添加剤成分が明らかにされていないが，多くの場 合 2 種類の添加椷が用意され，標準の添加量が示されている。 添加剂の濃度を一定に保つことが安定的な埋め込み特性を維 持するために重要であり, Cyclic Voltammetric Stripping (CVS) などを用いた濃度管理が行われる。

\section{3． Cu めっき膜中の不純物}

めっき膜中の不純物分析には, 2 次イオン質量分析 (SIMS) ${ }^{14) ~ 18) ~}$ や赤外吸収 (combustion-infrared absorption method) ${ }^{19)}$ が用いら れている。めっき膜中には，主に添加剤に由来する炭素 $(\mathrm{C})$, 塩素 $(\mathrm{Cl})$, 硫黄 $(\mathrm{S})$ が含まれる。C はサプレッサ成分の $\mathrm{PEG}$ が $\mathrm{Cl}$ と複合体を形成してめっき表面に吸着し, 膜中に取り 込まれると考えられている。また $\mathrm{S}$ はアクセラレータ成分 の SPS に由来すると考えられるが, 膜中に取り込まれるこ となく，めっき表面に留まり，Cや $\mathrm{Cl}$ に比較して膜中の濃 度はSIMS の検出限界に近い非常に低い值である。

めっき膜中の不純物量は, 添加剂濃度が多いほど増加する ことが知られている。一方, ダマシン構造の配線パターン内 部の $\mathrm{Cu}$ においては, SIMS 分析により添加剤濃度を高くす ると, 不純物が高くなる結果 ${ }^{15)}$ と, 添加剂濃度と膜中の不 純物濃度の相関がみられないという結果 ${ }^{18)}$ が報告されてい る。 $\mathrm{Cu}$ 中への不純物の取り込みが，めっき表面への添加剤 成分の吸着量, 濃度, $\mathrm{Cu}$ 堆積速度などによって变化するため, 場所やパターンによってこれらが変化し, 差が生じているも のと思われる。配線幅依存性に関して, 配線幅が狭いほど不 純物濃度が高くなるという結果が報告されている ${ }^{17)}$ 。以下 では，平坦なめっき膜中の不純物について我々の結果を中心 に述べる。

図 3 に, SIMS によるめっき膜中の不純物深さ分析結果の 一例を示す ${ }^{20)}$ 。ここで $\mathrm{Cu}$ めっき膜はスパッ夕法で堆積した $\mathrm{Cu} / \mathrm{Ta}$ 基板上に, 表 1 の成分のめっき浴を用いて, 電流密度 $10 \mathrm{~mA} / \mathrm{cm}^{2}$ で, 膜厚 $500 \mathrm{~nm}$ 堆積したものである。図 3 より めっき膜中に, $\mathrm{C}, \mathrm{Cl}, \mathrm{S}$ などの不純物が含まれていること がわかる。Taのプロファイルから銅めっき膜の位置がわか るが， Taのプロファイルより左側で $\mathrm{Cl}, \mathrm{S}$ が多く検出されて おり，前述のようにめっきの添加剂成分がめっき膜中に取り 込まれて，不純物として残留したものと考えられる。 の界面付近で $\mathrm{Cl}, \mathrm{S}$ の量が増えているのは，堆積初期におい て添加剤の吸着が多いことを示していると考えられる ${ }^{14)}$ 。C

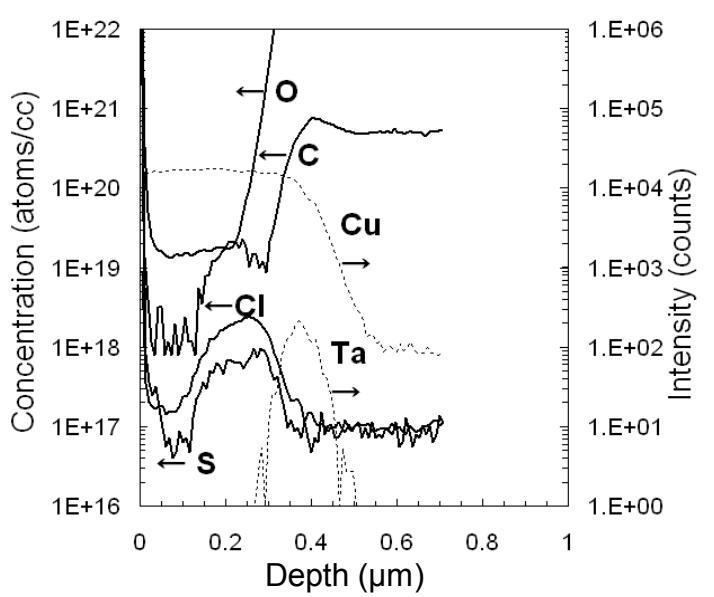

図 $3 \mathrm{Cu}$ めっき膜中の不純物の深さプロファイル例 (SIMS)

表 $1 \mathrm{Cu}$ めっき浴組成の例(本稿で紹介した実験で用いためっき浴)

\begin{tabular}{c|c}
\hline 組成 & 濃度 \\
\hline 硫酸 $(96 \%)(\mathrm{m} / / \mathrm{L})$ & 105.8 \\
硫酸銅 $(\mathrm{g} / \mathrm{L})$ & 65 \\
塩酸 $(35 \%)(\mathrm{ml} / \mathrm{L})$ & 0.12 \\
PEG $(\mathrm{mg} / \mathrm{L})$ & 100 \\
SPS $(\mathrm{mg} / \mathrm{L})$ & 1 \\
\hline
\end{tabular}

もめっき膜中に多く検出されているが, 添加剤濃度だけでな く, めっき液の溶媒である水の純度によっても, 残留する炭 素濃度が大きく変わる。図 3 のめっき膜は, イオン交換水(純 水)を用いたものであるが, 後述する超純水を用いためっき 浴の場合には, 膜中の残留炭素濃度は 1 桁以上減少する。

次に, 添加剤濃度によってどのように膜中の不純物が変化

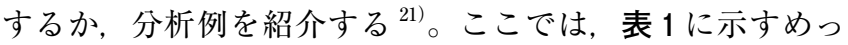
き浴を標準として, アクセラレータ (SPS), サプレッサ (PEG) をそれぞれ単独で変化させた時と, SPS と PEGの濃度比を 一定にして, 全体濃度を変化させた場合について述べる。めっ き条件は, 電流密度 $10 \mathrm{~mA} / \mathrm{cm}^{2}$ とし, 膜厚約 $500 \mathrm{~nm}$ を堆積 した。

図 4 (a) は，添加剤のうちアクセラレータである SPS の濃 度を変化させた時の膜中の炭素濃度プロファイル比較を示し ている。なお，この場合のみ，めっき浴の調整にイオン交換 水(純水)を用いたためべースとなる炭素濃度は, 図 2 と同様 に高くなっている。図4 (a)より, SPS 濃度の増加によって, 炭素濃度が減少することがわかる。この結果は, Cl-PEGに SPS を加えた場合のほうが炭素濃度が低くなるという Osaka らの結果 ${ }^{19)}$ と一致する。これは, SPS のめっき反応の促進作 用によって $\mathrm{Cu}$ の堆積速度が向上したか, あるいは West ${ }^{12)} や$ $\operatorname{Moffat}^{13)}$ が考えているようにめっき表面の吸着したサプレッ サ(Cl-PEG 複合体)の SPS による置き換えによって，めっき 膜への炭素の取り込み量が減少したためと考えられる。

図 4 (b) は, サプレッサである PEG の濃度を変化させたと きの炭素濃度プロファイル比較を示している。なお PEG 濃 度依存性と全体濃度依存性（図４（c））では，溶媒に超純水製 造装置を用いて作製した超純水を用いたため, 図 4 (a)の SPS 濃度依存性に比較してベースの炭素濃度が一桁以上減少 している。図4 (b)より, PEG 濃度が低いほうがわずかに炭 
(a)

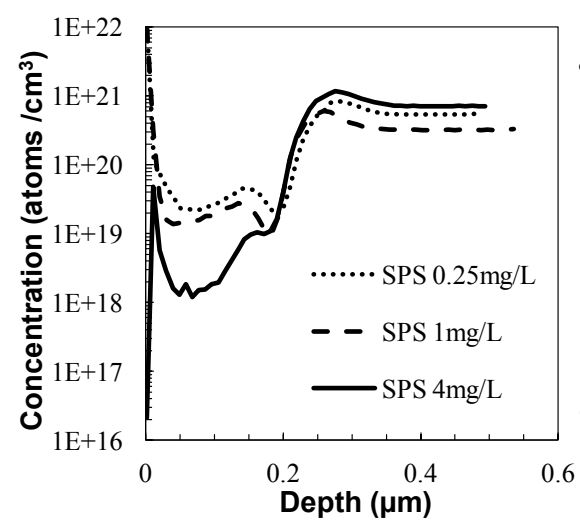

(b)

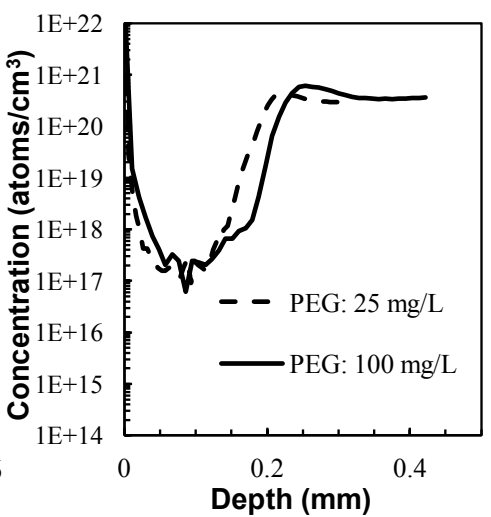

(c)

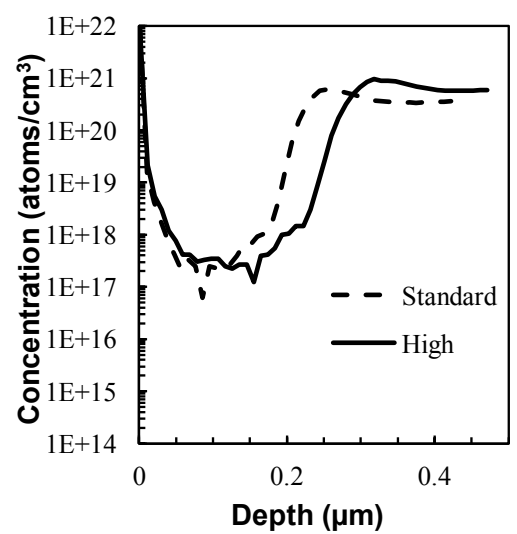

図 4 添加剂濃度による $\mathrm{Cu}$ めっき膜中の炭素 $(\mathrm{C})$ 濃度変化の SIMS 分析結果

（a）SPS 濃度依存性，（b） PEG 濃度依存性，（c)全体濃度(PEG/SPS) 依存性

素濃度は低くなっていることがわかる。結果をここに示して いないが, $\mathrm{Cl}$ も PEG 濃度が低いほうが，わずかに減少する 傾向が見られ, $\mathrm{Cl}$ は PEG との複合体としてめっき表面に吸 着してめっき反応を抑制すると考えられるので, $\mathrm{C}$ と $\mathrm{Cl}$ の増減が連動することは, 吸着したサプレッサの量 の変化として定性的に理解できる。最後に SPS と PEGの比 率を一定にして, 全体濃度を増やした場合においては, 図 4 (c)に示すように, 膜中の炭素濃度はほとんど変化しなかった。 $\mathrm{S}$ については, 濃度が $10^{16} \mathrm{~cm}^{-3}$ 以下の少ない量で検出下限 に近く, 正確な議論は難しいと考えられるが, 全体濃度を増 やした場合に, 多い傾向が見られ, 全体濃度を増やした場合 にめっき表面でSPS の濃度が増えることと定性的に一致す る。

Stangl らによれば，市販のめっき液(Enthone 社製)を用い ためっき膜においても, 全体の添加剤濃度の増加とともに, C, $\mathrm{S}, \mathrm{Cl}$ 濃度は増加する ${ }^{15)}$ 。また, Osaka らによれば, 添加剤 の組み合わせによって, 膜中の炭素濃度は変化し, Cl-PEG の組み合わせより, Cl-PEG-SPS の組み合わせのほうが炭素 濃度が少ない結果 ${ }^{19)}$ が報告されており, 上に述べた結果と 一致する。Osaka らによれば Cl-PEG の組み合わせにJGBを 添加すると, 炭素濃度は増加する。以上の結果を総合すると, めっき膜中の不純物量は, めっき反応が起きるめっき表面で の, サプレッサ成分 Cl-PEG とアクセラレータ成分 SPS の吸 着量が支配的な要因となっていると考えられる。

添加剂の量や比率は, 最適な埋め込み特性などを実現する ために最適化を行う必要があるが, 以上述べたように添加剤 濃度によって膜中の不純物量が変化し, それらが $\mathrm{Cu}$ めっき 膜の物性や配線特性に影響を与える。添加剤濃度は, これら の影響も考慮して決定する必要がある。以下に微細配線にお いて重要な不純物の影響として, 粒成長への影響と配線特性 への影響について解説する。

\section{4. 粒成長への不純物の影響}

$\mathrm{Cu}$ めっき膜では, 室温での堆積後から室温放置における 結晶粒成長 (再結晶化)であるセルフアニール現象が観察され,

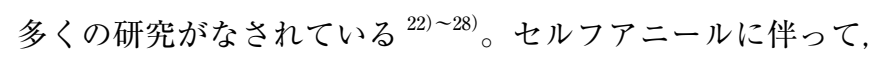

抵抗率の減少, 膜応力の変化, CMP 速度などの変化が生じる。 $\mathrm{Cu}$ 配線の製造プロセスにおいては, セルフアニールによる これらの物性変動は, 配線形状や特性のばらつきに繋がるた め, めっき後に $150{ }^{\circ} \mathrm{C}$ から $400{ }^{\circ} \mathrm{C}$ の間の温度で熱処理 (アニー ル)を行い, 結晶粒を成長させ, 物性の安定化が一般的に行 われる。セルフアニールや熱処理による粒成長には膜中の不 純物が影響する。以下に, 我々が行った添加剂濃度による $\mathrm{Cu}$ めっき膜の粒成長の変化を中心に, 膜中不純物の粒成長 への影響について述べる。なお, 我々の実験では, 粒成長を 促進する目的で熱処理と同時に電流密度 $0.1 \mathrm{MA} / \mathrm{cm}^{2}$ の電流 ストレスを印加した。

図 5 (a) は SPS 濃度を変化させたときの, 粒径の累積度数分 布の比較を示している。アニールは, 温度 $200{ }^{\circ} \mathrm{C} て ゙ ~ 0.1 \mathrm{MA} / \mathrm{cm}^{2}$ の電流を印加しながら, 窒素䨌囲気中で 30 分間行った。粒 径は, 結晶粒の面積を画像処理ソフトを用いて計算し, 面積 が同じとなる直径(等価円直径)を示している。SPS 濃度以外 のめっき条件は, 同じである。図 5 (a)に示すように SPS 濃 度が高いほど粒径が大きく, 粒成長が促進されていることが わかる。この時の膜中の炭素濃度は図 4 (a)に示したように, SPS 濃度が高いほうが低くなっている。なお, 前述のように PEG 濃度依存性, 全体濃度依存性の場合には, 溶媒として 超純水を用いたのに対して, SPS 濃度依存性の実験では純水 を用いたため, ベースの炭素濃度が高くなっている。

次に PEG 濃度を変化させた場合の粒径を比較した。アニー ルは, 温度 $300{ }^{\circ} \mathrm{C} て ゙ ~ 0.1 \mathrm{MA} / \mathrm{cm}^{2}$ の電流を印加しながら, 真 空中で 30 分間行った。図 5 (b) に示すようにPEG 濃度を低 下することで，わずかに粒径が大きくなる傾向が見られた。 この場合の膜中の炭素濃度は, PEG 濃度の低下に伴って, わずかに低い傾向が見られるが, 図 5 (a)に示す SPS 濃度を 4 倍にした時の変化に比較して, PEG 濃度を $1 / 4$ にした時の 変化は, 膜中の炭素濃度, 粒径いずれへの影響も小さい。

図 5 (c) は, PEG と SPS 濃度の全体を変化させたときの粒 径分布の比較で, アニール条件は図 5 (b) の PEG 濃度依存性 と同じである。添加剤の組成比は一定であるが, 全体濃度が 高い場合 (SPS/PEG ともに4 倍)に, 粒径が大きくなっている。 この場合の膜中炭素濃度の変化は, 図 4 (c) に示したように, 
(a)

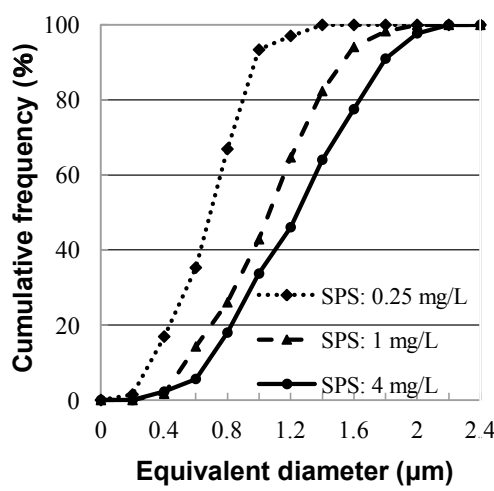

(b)

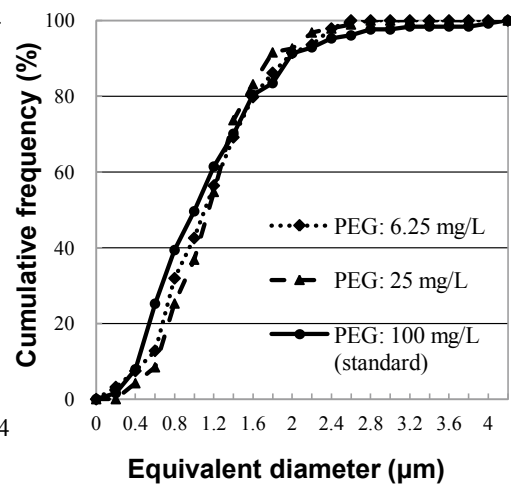

(c)

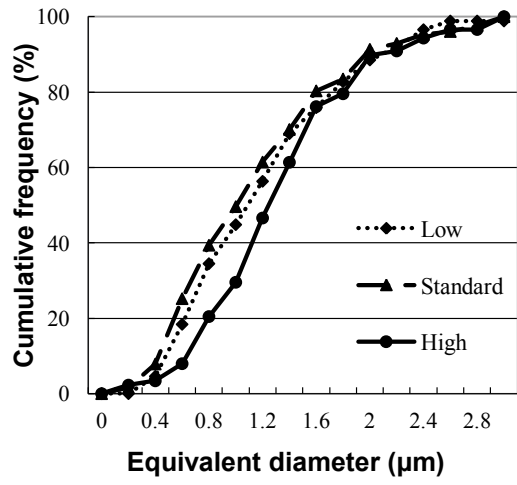

図 5 粒径分布の添加剤濃度依存性

（a）SPS 濃度依存性，（b) PEG 濃度依存性，（c) 全体濃度依存性（PEG/SPS 比一定）

ほとんど同じであった。

SPS 濃度依存性の結果および PEG 濃度依存性の結果から, 膜中の炭素濃度が高くなるにつれて粒径が小さくなる傾向が 見られた。その理由として図 6 に示すように, 粒界に存在す る不純物 (炭素)によって粒界移動のピンニングが生じ ${ }^{27), 29)}$, 粒成長が抑制された可能性が考えられる。一方, 図 5 (c)に 示した全体濃度依存性においてほぼ同じ炭素濃度でも, 全体 濃度が高い場合に粒成長が促進されていることから, SPS に 炭素濃度を減少させる作用以外に粒成長を促進させる作用が ある可能性が考えられる。Osaka らは添加剤の組み合わせに よるセルフアニールの有無を調べ, SPS を添加した場合には セルフアニールが見られるが, SPS が入っていない Cl-PEG 添加, Cl-PEG-JBG 添加では, セルフアニールが観察されて いないことを報告している ${ }^{19)}$ 。また, Stangl らの添加鼡濃度 全体を変化させた時のセルフアニール時間比較 ${ }^{15)}$ では，添 加剂なしではセルフアニールが生じないが，添加剤を入れる とセルフアニールが生じ, 添加剤濃度が増えるとともに粒成 長までの時間が少しずつ増加するという結果を示し，膜中不 純物によるピンニングにより説明している ${ }^{15)}$ 。

以上述べたように，めっき膜中の不純物によって，めっき 膜の粒成長 (再結晶化) は影響を受け，炭素濃度が高い場合に は図 6 に示すピンニング効果によって粒成長が抑制される傾 向がある。またSPS にはセルフアニールを誘因する作用が あり, 膜中の炭素濃度を下げる作用により粒成長が促進され ると考えられる。粒成長は，以下に述べる抵抗や信頼性，膜 応力 (引っ張り応力の増加) など配線の特性や信頼性に影響を
与えることになる。

\section{5．配線抵抗と信頼性への不純物の影響}

ここでは配線抵抗と, 信頼性としてエレクトロマイグレー ション(EM : Electromigration), ストレス誘起ボイド(SIV : Stress-induced Void)への不純物の影響について述べる。

まず配線抵抗への不純物の影響は, 不純物散乱による直接 的な作用と，粒径を介した間接的な作用がある。特に配線幅 が $100 \mathrm{~nm}$ 以下の微細配線では，図 7 に示すように電子の粒 界散乱や側面散乱による抵抗上昇の影響が大きく，抵抗低減 のためには，粒径の拡大が重要となる。前節で示したように， SPS 濃度を相対的に増加することで粒径を大きくでき，さら に膜中の炭素濃度も減少するので, 低抵抗化につながると考 えられる。Osaka らによれば, 膜中の炭素濃度とセルフアニー ル後の $\mathrm{Cu}$ めっき膜の抵抗率の間には正の相関がみられる ${ }^{19)}$ すなわち，炭素濃度が高いほど抵抗率が高くなる。この結果 からも膜中の炭素濃度を減らすことが, 低抵抗化につながる と考えられる。

EM 信頼性への影響では，不純物濃度が増加するほど EM 寿命が劣化する ${ }^{16), 30), 31)}$ 。その理由は図 8 に示すように, めっ き膜中に含まれる不純物が熱処理によって銅配線と絶縁膜と の界面に析出し, 界面の密着性が低下するからである。ちな みに $\mathrm{Cu}$ 配線の $\mathrm{EM}$ においては， $\mathrm{Cu}$ 配線と絶縁膜の界面が, $\mathrm{EM}$ による $\mathrm{Cu}$ の拡散パスであり, 密着性の劣化は拡散速度 の増加につながる。Stangl らは, アニールによって界面に析 出する $\mathrm{C}$ と $\mathrm{S}$ の量がアニール時間とともに増え, 添加剤濃
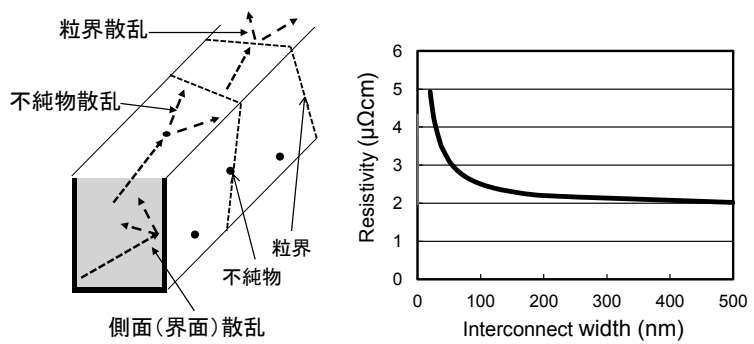

図 7 微細 $\mathrm{Cu}$ 配線における電子散乱の模式図(左) と電子散 乱効果による抵抗率上昇(右)
図 6 不純物によるピンニングの模式図(左)と $\mathrm{Cu}$ めっき膜 の粒構造の例 (右, FIB/SIM 像に粒界を書きいれたもの)
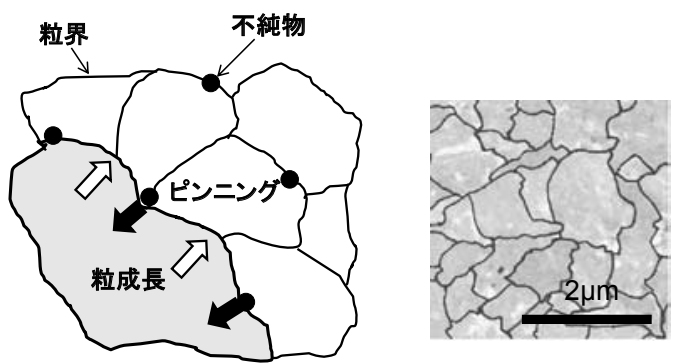

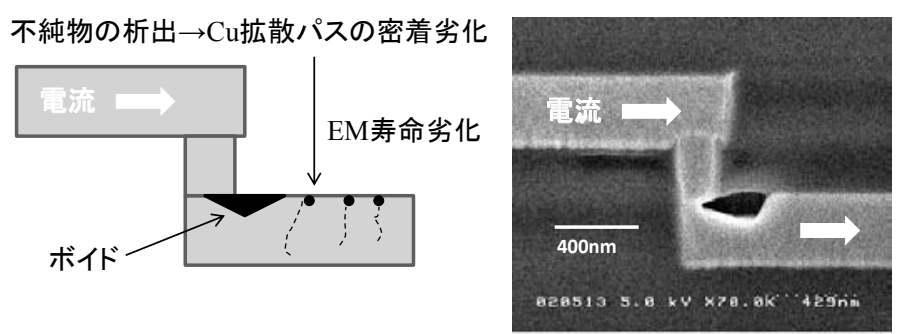

図 $8 \mathrm{Cu}$ 配線の EM における不純物の影響の模式図(左)と EMによるボ イド観察例(右：断面 SEM 写真)
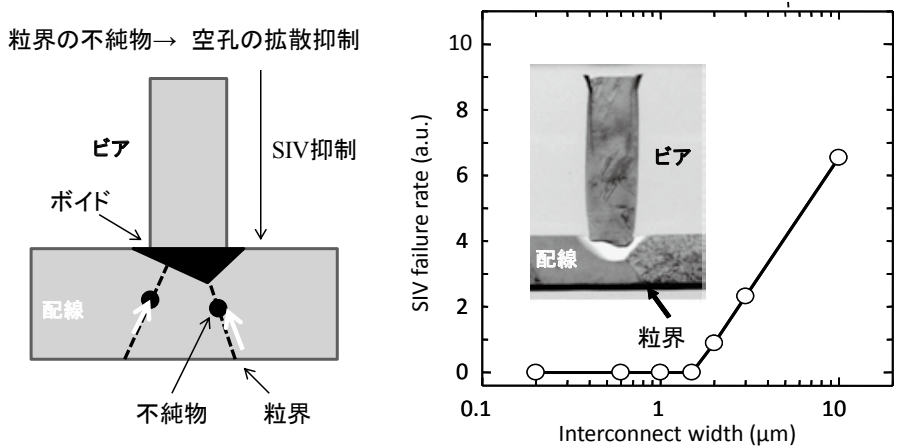

図 $9 \mathrm{Cu}$ 配線の SIV における不純物の影響の模式図(左)と SIVによるボ イド観察例および SIV 発生率の配線幅依存性(右：断面 SEM 写真)

度が高いほど析出量が多いことを示している ${ }^{16) 。 ま た ~ A l e r s ~}$ らは不純物の多いほうが界面でのマイクロボイドが多い結果 を示している ${ }^{30)}$ 。マイクロボイドは, EMによるボイドの起 点や空孔の供給源となるため, EM劣化につながる。

一方，SIVへの不純物の影響では，不純物は EM とは逆に SIV 抑制の効果が報告されている ${ }^{31}$ 。これは図 9 に示すよう に，炭素などの粒界の不純物が，粒界を介した空孔の拡散を 抑制し，ボイドの形成を抑制すると考えられるからである。

このように不純物濃度は, EM と SIV に関して, 効果のト レードオフがある。すなわち不純物を増やすと SIV は抑制 されるが，EM 耐性が劣化する。このトレードオフを解決す る手段として，Shih らは分子量の大きなレベラーを用いる 方法を提案した ${ }^{311}$ 。図 9 の右の図に示すように SIV は幅依 存性を持ち, 幅の広い配線において顕著であるため, 幅の広 い配線中の不純物を増やすことが有効と考えられる。一方， 狭い配線では SIV は生じにくく EM 耐性が問題なので，狭 い配線には不純物をなるべく導入しないようにする必要があ る。分子量の大きなレベラー分子は, 広い配線溝には入るこ とができるが, 狭い配線幅には侵入しにくい。この原理を使っ て, 広い配線の不純物濃度を選択的に上げ，狭い配線では不 純物濃度を低くすることができ，これによって SIV と EM のトレードオフが解決されるとしている。

\section{6. おわりに}

本稿では，微細配線に用いられる銅めっき膜の不純物につ いて，分析結果を示し，その影響について述べた。

銅めっき膜には, めっき浴に含まれる不純物や添加剤から の残留によって $\mathrm{C}, \mathrm{S}, \mathrm{Cl}$ などが存在し，不純物量は添加剂
の量によって変化する。

添加剂の内, 促進成分である SPS の添加量を増やすと, 膜中の炭素が減少し, 抑制成分の PEG の添加量を減らすと 炭素の濃度が若干低下する。同じく抑制成分のレベラーの添 加量を増やすと膜中の不純物量は増加する。めっき反応では, めっき表面に存在する抑制成分 Cl-PEG 複合体と促進成分 SPS の競合関係でめっき膜中に取り込まれる不純物量が決ま ると考えられる。

膜中の不純物は, セルフアニールや熱処理による粒成長 (再 結晶化)に影響する。炭素は粒界に集合し粒界の動きをピン ニングすると考えられ, 膜中の炭素濃度が高いほど, 粒成長 しにくくなる。一方，SPS は炭素濃度を低下させる作用だけ でなく，七ルフアニールを生じさせ，粒成長を促進する作用 があると考えられる。

不純物は, 不純物散乱や粒界散乱を介しては電気抵抗に影 響し，炭素などの不純物が増加するほど抵抗が高くなる。ま た不純物は，粒界のピンニング作用や粒界拡散の抑制作用に よって SIV の改善に効果を有する一方で，EM に対しては銅 / 絶縁膜界面への不純物の析出によって界面の密着性を劣化 させ，EM 寿命を低下させる。SIV と EMのトレードオフを 解決するために添加剤分子の工夫が提案されている。

銅配線では微細化の進展とともに，電子散乱効果による抵 抗率の上昇や，信頼性劣化が深刻になるため，今後ますます めっき膜中の不純物制御が重要になると考えられる。また, 本稿では触れなかったがチップを積層する三次元集積技術が 進展して打り，それに用いる TSV (Through Silicon Via) 用の 銅めっきに扔いても，応力によるデバイス特性変動を抑制す るため, 不純物の制御が重要と考えられる。 
謝辞

本稿で紹介した研究の共同研究者である芝浦工大大学院生 の Liyana Razak 氏, 山口貴雅氏，東レリサーチセンターの橋 本秀樹氏，赤堀誠至氏に感謝いたします。また紹介した研究 の一部は, 文部科学省科研費補助金 (No.22560344)を受けて 実施されました。

(Received February 20, 2012)

\section{文献}

1) D. Edelstein, J. Heidenreich, R. Goldblatt, W. Cote, C. Uzoh, N. Lustig, P. Roper, T. McDevitt, W. Motsiff, A. Simon, J. Dukovic, R. Wachnik, H. Rathore, R. Schlz, L. Su, S. Luce, and J. Slattery ; 1997 IEEE Int. Electron Devices Meet.,Digest, 241 (IEEE, 1997).

2 ) 新宮原正三, 粟屋信義, 上野和良, 三沢信裕 (編); Cu配線技術の最 新の展開(リアライズ社, 1998).

3 ) 吉川公麿 (監修); 次世代ULSI多層配線の新材料・プロセス技術 (技術情報協会, 2000).

4) International Technology Roadmap for Semiconductors 2009 Edition, Interconnect (2009).

5 ) M. Bohr ; 1995 IEEE Int. Electron Devices Meet., Digest 241 (IEEE, 1995).

6 ) P. C. Andricacos, C. Uzoh, J. O. Dukovic, J. Horkans, H. Deligianni ; IBM J. Res. Dev., 42, 567 (1998).

7 ) J. J. Kelly, A. C. West ; Electrochem. Solod-State Lett., 2, 561 (1999).

8 ) P. Taephaisitphongse, Y. Cao, A. C. West ; J. Electrochem. Soc., 148, C492 (2001).

$9)$ V. M. Dubin, R. Akolkar, C. C. Cheng, R. Chebiam, A. Fajardo, F. Gstrein ; Electrochimica Acta, 52, 2891 (2007).

10) J. Reid, S. Mayer, E. Broadbent, E. Klawuhn, K. Ashtiani ; Solid State Technology, 43, 86 (July 2000).

11) P. M. Vereecken, R. A. Binstead, H. Deligianni, P. C. Andricacos ; IBM J. Res. Dev., 49, 3 (2005)

12) A. C. West, S. Mayer, J. Reid ; Electrochem. Solid State Lett., 4, C50 (2001)

13) T. P. Moffat, D. Wheeler, W. H. Huber, D. Josell ; Electrochem. Solid State Lett., 4, C26 (2001).

14) M. Stangl, J. Acker, S. Oswald, M. Uhlemann, T. Gemming, S.
Baunack, K. Wetzig ; Microelectron. Eng., 84, 54 (2007).

15) M. Stangl, M. Liptak, A. Fletcher, J. Acker, J. Thomas, H. Wendrock, S. Oswald, K. Wetzig ; Microelectron. Eng., 85, 534 (2008).

16) M. Stangl, M. Liptak, J. Acker, V. Hoffmann, S. Baunack, K. Wetzig ; Thin Solid Films, 517, 2687 (2009).

17) W. Zhang, S. H. Brongersma, N. Heylen, G. Beyer, W. Vandervorst, K. Maex ; J. Electrochem. Soc., 152, C832 (2005).

18) J. Neuner, I. Zienert, A. Peeva, A. Preusse, P. Kucher, J. W. Bartha ; Microelectron. Eng., 87, 254 (2010).

19) T. Osaka, N. Yamachika, M. Yoshino, M. Hasegawa, Y. Negishi, Y. Okinaka ; Electrochem. Solid-State Lett., 12, D15 (2009).

20) K. Ueno, Y. Shimada, S. Yomogida, S. Akahori, T. Yamamoto, T. Yamaguchi, Y. Aoki, A. Matsuyama, T. Yata, H. Hashimoto ; Jpn. J. Appl. Phys., 49, 05FA08 (2010)

21) L. Razak, T. Yamaguchi, S. Akahori, H. Hashimoto, K. Ueno ; Jpn. J. Appl. Phys., 51, to be published (2012).

22) T. Ritzdorf, L. Graham, S. Jin, C. Mu, D. Fraser ; Proc. 1998 International Interconnect Tech. Conf, 166 (1998, IEEE).

23) C. Cabral, Jr., P. C. Andricacos, L. Gognac, I. C. Noyan, K. P. Rpdbell, T. M. Shaw, R. Rosenberg, J. M. E. Harper, P. W. DeHaven, P. S. Locke, S. Malhotra, C. Uzoh, S. J. Klepeis ; Proc. 1998 Advanced Metallization Conf., 81 (1999, MRS).

24) C. Lingk, M. E. Gross, W. L. Brown, W. Y. -C. Lai, J. F. Miner, T. Ritzdorf, J. Turner, K. Gibbons, E. Klawulm, G. Wu, F. Zhang ; Proc. 1998 Advanced Metallization Conf., 73 (1999, MRS).

25) K. Ueno, T. Ritzdorf, S. Grace ; Proc. 1998 Advanced Metallization Conf., 95 (1999, MRS).

26) Q- T. Jiang, K. Smekalin ; Proc. 1998 Advanced Metallization Conf., 209 (1999, MRS).

27) J. M. E. Harper, C. Cabral, Jr., P. C. Andricacos, L. Gignac, I. C. Noyan, K. P. Rodbell, C. K. Hu ; J. Appl. Phys., 86, 2516 (1999).

28) K. Ueno, T. Ritzdorf, S. Grace ; J. Appl. Phys., 86, 4930 (1999).

29) C. Zener ; Trans. AIME, 175, 15 (1948).

30) G. B. Alers, X. Lu, J. H. Sukamto, S. K. Kailasam, J. Reid, G. Harm ; Proc. International Interconnect Tech. Conf., 45 (2004, IEEE).

31) C. H. Shih, S. W. Chou, C. J. Lin, T. Ko, H. W. Su, C. M. Wu, M. H. Tsai, W. S. Shue, C. H. Yu, M. S. Liang ; Proc. International Interconnect Tech. Conf., 102 (2005, IEEE). 